\title{
Family Archives in Pre-Transition Egypt
}

The first two words of my title may have given too many hostages to fortune; I shall begin by saying how I am using them. First, "archives." There is a long discussion of the term "archive" in papyrological discourse, which I do not need to recount. I am adopting the broad understanding used by Trismegistos archives and justified in Bart Van Beek's paper at the Helsinki papyrological congress, drawing in its turn on the typology established by Andrea Jördens. ${ }^{1}$ The actual circumstances and characteristics of individual archives, however, are of some interest for the questions I shall be discussing.

"Family" is no simpler. Van Beek apparently equates "family" and "private," whereas Katelijn Vandorpe has noted the distinction to be made between "personal" and "family," the latter requiring more than one generation to fit the definition. ${ }^{2}$ Trismegistos has not adopted this distinction in any significant way; only one archive, that of Leon from the Ptolemaic period, is actually called "personal" in Trismegistos. I have not been able to discover any consistent principle for usage of "family" and "private" in the TM records, although "private" does include business archives, apparently distinguished from family archives. Here, too, I have adopted a broad definition: I have chosen to include a number of the so-called private archives in my discussion wherever they did not seem limited to extrafamilial business. ${ }^{3}$

The central question that interests me here is the way in which we write the social and economic history of Egypt in Late Antiquity, using that term here in a broader sense that spans the period from Diocletian to the Arab conquest rather than in the narrower way I did in my book on the subject a quarter-century ago. ${ }^{4}$ Although that history is inevitably at times quantitative and analytic, it is also narrative, and archives have been central to the storytelling that papyrologists do about the society of Roman Egypt.

Everyone needs stories to make sense of the world, whether of today or of a millennium and a half ago; we are all constantly fashioning our lives into narratives, even if only for ourselves. But storytelling is, I believe, even more necessary for historians using papyrological evidence than for other people. This need is the result of the sketchy evidence we possess combined with the human interest inherent in what

1 Van Beek (2007) 1033-1037, citing Jördens (2001) as well as earlier discussions by Pestman (1990) and Martin (1994). For TM Archives see http://www.trismegistos.org/arch/index.php.

2 Van Beek (2007) 1039; Vandorpe (2009) 233-234.

3 The TM archive numbers are given for each archive at first mention in the detailed analysis below. An asterisk indicates that a more developed discussion of the archive is provided in TM. Because TM gives a bibliography for each archive, I have omitted detailed bibliographical references except for newer work not reflected there as of the date of writing.

4 Bagnall (1993); cf. also Bagnall (2003) on issues of periodization.

https://doi.org/10.1515/9783110683554-014 
material we do have. The most obvious example of our narrative habits is the way the upper-middle class residents of Oxyrhynchos - almost like us, we imagine - tend to dominate the picture of urban life in Roman Egypt. Sometimes this is purposeful, as in Peter Parsons's elegant City of the Sharp-Nosed Fish, deliberately and explicitly about Oxyrhynchos; ${ }^{5}$ sometimes it is more implicit, as in Naphtali Lewis's Life in Egypt under Roman Rule, where Oxyrhynchos has more lines in the index than any place except Alexandria. ${ }^{6}$ It is our type-city, and to the extent that it may not in fact have been typical, centering our accounts on it runs some risks of presenting a distorted picture.

With villages, matters are not so straightforward. There is no one village that dominates our picture of rural Egypt in the Roman period. Once again, Lewis's index can give a snapshot: for Karanis, 14 references; for Soknopaiou Nesos, 11; for Philadelphia and Tebtynis, 6 each; Theadelphia, 4. Given the unusual nature of Soknopaiou Nesos as temple community, pilgrimage destination, and customs post, it can hardly serve as a type-site for papyrological storytelling, and it is in fact Karanis and Tebtynis that are our richest sites for the human dimensions of the papyri, as well as providing the richest archaeological contexts for the documents. It is thus perhaps all the odder that Karanis lacks a proper village history, the closest equivalent being Hanna Geremek's short monograph, focused largely on administrative matters. ${ }^{7}$

For a later period, the tremendous growth in the study of the archives of the Apiones and of the family of Dioscorus of Aphrodito in the intervening period has brought into the foreground the centrality of archives in shaping the questions we can and do ask about particular times and our dependence on the nature of these archives for how we approach the subject. ${ }^{8}$ The contrast between the Oxyrhynchos of the Apiones and the Aphrodito of Dioscorus has given rise to quite a bit of rewarding discussion, both of substance and of method, about what kind of a society sixthcentury Egypt was, and to what extent our picture of that society has been dictated by the character of these archives. ${ }^{9}$

That we would ask this question in just this way is in part a reflection of how few other substantial archives we have from the period after the middle of the fifth century, and that relative poverty leads me to look back at the span from Diocletian to the first half of the fifth century and the contrast that it presents in its relative abundance of archives, which certainly had a profound impact on how I approached the task of describing that period. In particular, the central role of the Karanis family archives is hard to escape. I shall therefore look at the archival picture of the whole late

5 Parsons (2007).

6 Lewis (1983).

7 Geremek (1969).

8 The bibliography on both archives is vast, and its essential elements may be found in Trismegistos. I would call attention here particularly to Fournet/Magdelaine (2008) for the Dioscorus archive. 9 See, for example, Hickey (2007), Keenan (2007), and Ruffini (2008). 
antique period and think about the reasons why it looks as it does and about its impact on our history-writing. ${ }^{10}$

The fourth century does in fact seem in retrospect like a golden age for family archives. We find them coming from both village and city settings. It is probable that all of them come from excavations, whether scientific or (mostly) clandestine, of settlement areas rather than that they were found in external dumps. The core archives here are those of Isidoros (TM Arch ID 34*), Aion and Valerius (250*), and Tetoueis $\left(30^{\star}\right)$, all from Karanis; of Pamour (508), from Kellis; of Serenos, from Trimithis (not included in Trismegistos; see O.Trim. I and II); of the nekrotaphoi of Kysis (147), bridging the period from the 230s to 314 (now reedited in P.Nekr.); the multigenerational archive of Charite, Adelphios, Asklepiades (28) from Hermopolis; and the archives of Ammon scholastikos (31*) and Alopex (317*) from Panopolis.

For some of these we know quite a bit about the circumstances of discovery. The Kellis papyri were all found in controlled excavations, and in particular of fourthcentury houses in Area A. Probably none of the papers of the inhabitants of these houses were found in a primary use context, as pieces were found scattered across more than one house and even outside them. But if the material was all discarded at least it was thrown away more or less where used. The ostraka of Serenos from Trimithis were found on occupation floors in both his house and in the adjoining stables and storage building. The papers of the nekrotaphoi were acquired on the antiquities market, but local informants many decades later told Françoise Dunand that they had come from a house in the necropolis, plausible even if hardly certain. Ammon and Alopex are both archives acquired on the antiquities market, and although a certain amount of the acquisition history can be traced, Trismegistos can report no information on the original circumstances of discovery.

The situation with Karanis is more complicated. The published papyri of the three connected family archives that I mentioned come more or less entirely from purchases on the antiquities market, mainly in the 1920s. But there are papyri in the Michigan collection coming from the Karanis excavations of the 1920s and 1930s that are parts of these archives; little of this material has been published so far. A project initiated by Graham Claytor, and involving also Rodney Ast, Jennifer Sheridan Moss, and me, aims to publish all of this material and to look closely at the find context information for the excavated pieces to try to push forward knowledge of the findplaces of these archives. It is a reasonable surmise that they come, like some other Karanis archives, from storage or dump sites within the village settlement rather than from primary domestic use locations.

About the Hermopolitan family archives, perhaps best described (with Fritz Mitthof) as the archive of Asklepiades and his parents and grandmother - i.e., Demetria alias Ammonia, Charite, and Adelphios - nothing is known of the find circumstan-

10 On writing history from the papyri, see my reflections in Bagnall (1993) 3-14 and more generally Bagnall (1995, 2nd ed. 2019). 
ces. Klaas Worp established that the Viennese component of this archive came as a single acquisition, probably in 1886; he surmises that the Cairo parts of the archive were acquired around the same time. ${ }^{11}$

The absence of Oxyrhynchos from this list is striking. The entire third- to fourthcentury span yields only four private archives: Diogenis alias Tourbiaina (29), Serenus (38), Apia (53), and Sarapion alias Apollonianos and his sons (210). These are mostly small, with Diogenis having just 4 texts, Apia having only 18 texts scattered across 8 collections, and Serenus just 10 texts, all in P.Oxy. The only larger instance is the classic case of Sarapion alias Apollonianos, which should be called a family archive, as it includes multiple generations; but its 58 texts are very scattered, across 16 collections. The common thread in the Oxyrhynchite picture is probably an archaeological phenomenon: all of these were really found in dumps, whether by Grenfell and Hunt, by the Italian mission, or by private excavation, and not in domestic contexts (or even in contexts of domestic discarding). Of course Oxyrhynchos totally dominates discussion of public institutions in the fourth century, because of the masses of official documents found in the dump, covering the period down to the 370 s very richly. ${ }^{12}$ The contrast between the public and the private sides of the Oxyrhynchite documentation is striking.

It is no surprise that the fifth century is less rich in family archives, as it is in almost all respects in our documentation. ${ }^{13}$ The most striking aspect apart from small numbers is that none come from villages. The three family archives from urban settings were all apparently deposited in the sixth or seventh century, thus lasting for generations. One of them, of course, is the massive Apiones archive, which gets its start in the fifth century. But it is not clear that it should properly be classified as a family archive; the papers in fact reflect a business office operating in the nome capital on behalf of the family rather than of family affairs per se. Also from Oxyrynchos is the small archive concerning Flavius Eulogios and his sons Apphous and Martyrios (82*), similarly composed of business papers that could have come from such an office, although that of a lesser magnate than the Apiones or Anastasia. Most of the 14 certain texts were found in the first season of the Oxyrhynchos excavations, three more from a return to the same mound in the sixth season, and one acquired through the papyrus cartel of Bell, probably a clandestine find from the same mound.

From Hermopolis we have the substantial true family archive of Taurinos and his descendants, which is much more like the fourth-century family archives in its char-

11 P.Charite, p. 1; CPR XVII A, p. 7. On the unity of the archive, see Martin (1994) 576-577; on the nature and ownership of the archive, F. Mitthof, P.Kramer, p. 134-138. Mitthof also raises the possibility (136-137 n. 10) that Asklepiades was not the last holder, and that the papers of the two Nearchidai from the second half of the fourth century are part of the same find.

12 Most richly represented in P.Oxy. LIV, where Revel Coles gathered texts relevant to the office of logistēs (curator civitatis).

13 See already Bagnall/Worp (1980), and from a statistical point of view, Habermann (1998). 
acter than are the Oxyrhynchite archives (259*). Its 56 certain, perhaps as many as 75 , texts, all in Berlin, were mostly found by Rubensohn in 1905 in the excavation of a dump, and a few less precisely documented may come from the same find. It seems in fact to be rather a sprawling assemblage of documents reflecting several families. For the most part the documents are characteristic of patrimonial management of a wealthy urban family, with a military background, but not of the class of magnates. Similar but much smaller is the Hermopolite archive of Flavius Silvanus and his son Flavius Georgios; Silvanus was also a soldier, but as with Taurinos the archive focuses on family business activities - leasing and lending, particularly. Unfortunately, the detailed circumstances of finding seem to be irretrievable, as all of the known texts of this archive come from purchases in the antiquities market. ${ }^{14}$ Finally, the earliest document of the Patermouthis archive from Syene belongs to the fifth century, but as it is an outlier in a group otherwise belonging to the later sixth and early seventh century, it can be left out of account for the moment.

The sixth-century documentation is dominated by the Apiones and the Aphrodito archives of Dioscorus (72) and Phoibammon (193), the first found in 1905 in a single place in Kom Ishqaw, the second discovered only in the 1940s and reaching the market in very dispersed fashion, without reliable provenance information. ${ }^{15}$ It is not doubtful, however, that both were found in the settlement context of Aphrodito. The Oxyrhynchite offers also from this century the rest of the documents concerning Eulogios's sons Apphous and Martyrios and the papers of another magnate, Anastasia (11). The small (11 texts) bilingual archive of contracts involving the purple-dealer Pachymios $\left(36^{\star}\right)$ continues into the seventh century. It was discovered in the nineteenth century, but nothing seems to be known of the find circumstances. The activities of Pachymios and his family spanned Panopolis and This.

The more substantial archive of Patermouthis of Syene $\left(37^{\star}\right)$, with more than 50 texts in Greek and Coptic, also spans the centuries. It was acquired by purchase, with some texts divided in the process between London and Munich. It has been shown by Jitse Dijkstra that this archive was found, by clandestine excavations, in the ruins of Aswan, north of the Cataract Hotel, and thus belongs to an urban milieu. ${ }^{16}$ Dijkstra concludes that it is likely that Patermouthis lived in this part of the town, and that "the papyri would then have been disposed of after his death in or near his house."17

The seventh century brings the endings of some archives already mentioned, but not a lot new. From Aphrodito, Trismegistos lists the archive of the sons of Christophoros (429), but it attributes zero texts to it citing a forthcoming study by Jean-Luc Fournet as having established that this is in fact part of the archive of Phoibammon -

14 See the chapter of Isabelle Marthot-Santaniello in this volume.

15 Fournet/Magdelaine (2008) 18-19, promising a detailed study of the find circumstances of the first archive.

16 Dijkstra (2007) 196-209.

17 Dijkstra (2007) 208. 
a ghost-archive, as it were. ${ }^{18}$ At Edfu we get the handful of texts of Philemon and Thekla (190), basically the massive Budge Papyrus in Coptic and three Greek texts in London surrounding it, all concerning a house. These were, as Schiller reports, "seemingly unearthed by sebakh diggers in the early years" of the twentieth century - probably in a house on the tell of Edfu, as Wilcken surmised. ${ }^{19}$ Finally, the small archive or dossier of another magnate with fiscal responsibilities, Sophia patricia, and perhaps the mother of Theodosios (490), Theodosiopolite in content, was found at Arsinoe as part of the great mass of documents that came onto the market from that site in the late nineteenth century, although it is impossible to say where at Kiman Fares they were found. ${ }^{20}$ Eighth-century archives, beyond the scope of this paper, are mainly monastic or official in character, with limited family content; the business papers on ostraka of Koloje and her family are perhaps the most salient family papers of this era, probably going back as far as Koloje's grandmother Katharon, as Seÿna Bacot has argued, and were found in the town of Jeme. ${ }^{21}$

How are we to interpret these data? If one looked at this list quantitatively, it might appear to comfort theories of decline. But of course it does little more than track the overall pattern of documentation in this period, so the decline in family archives is probably not in itself of significance. The same can be said for the almost total domination of city archives rather than village, with Aphrodito the only village to provide family archives after the fourth century and before the Arab conquest. But again, the same is essentially true of the documentation generally, with only minor exceptions. This is not a characteristic distinctive to archives.

These two points argue for what I would call an archaeological interpretation: contingent factors have led to few excavations of city and village sites from the last centuries of Roman rule, and monasteries do not yield family archives. The numbers of family archives thus do not have any special significance. Indeed, I would suggest that instead their importance lies in their very existence and the types of documents included. Village elites, urban artisans, and metropolitan landowners, the creators of these archives, are merely the latest representatives of social groups well known from earlier centuries, accumulating the documentation of their acquisition and management of land, defense of rights, creation and dissolution of family relationships, payment of taxes, borrowing and lending of money, and so on with documents of types which we are familiar. This phenomenon points to a stability both of substance and of documentation across a period that certainly saw many other changes.

The number of archives that close shortly before the Persian invasion might lead one to ask if this stability breaks down at that time. On the whole, the Philemon and Thekla papers, along with the later parts of the Phoibammon archive, would lead one

18 This study has now appeared as Fournet (2016).

19 Schiller (1968) 79, citing Wilcken (1953) 120-22.

20 Gonis (2008) 204-206.

21 Wilfong (1990) and (2002); Bacot (1999). 
to say that not a great deal changed in this respect. But of course there is a substantial shift in this period toward the use of Coptic for true legal documents, a subject most recently and comprehensively treated in Jean-Luc Fournet's Rostovtzeff Lectures at the Institute for the Study of the Ancient World (New York University) in spring 2017. ${ }^{22}$ Despite that, the continuity in documentation practices and in the normal activities of the propertied parts of society, both rural and urban, seem to me more striking than the changes.

\section{Bibliography}

Bacot (1999): Seÿna Bacot, “Avons-nous retrouvé la grand-mère de Koloje?”, in: Stephen Emmel et al. (eds.), Ägypten und Nubien in spätantiker und christlicher Zeit. Akten des 6. Internationalen Koptologenkongresses Münster, 20.-26. Juli 1996 (Sprachen und Kulturen des christlichen Orients VI), Wiesbaden, vol. II, 241-247.

Bagnall (1993): Roger S. Bagnall, Egypt in Late Antiquity, Princeton.

Bagnall (1995, 2nd ed. 2019): Roger S. Bagnall, Reading Papyri, Writing Ancient History (Approaching the Ancient World), London.

Bagnall (2003): Roger S. Bagnall, “Periodizing when you don’t have to. The concept of Late Antiquity in Egypt”, in: B. Sirks, ed., Gab es eine Spätantike? Vier Vorträge, gehalten auf der Tagung des Graduiertenkollegs für Antike und Europäische Rechtsgeschichte am 21. Juni 2002, Frankfurt am Main, 39-49.

Bagnall/Worp (1980): Roger S. Bagnall and Klaas A. Worp, "Papyrus documentation in Egypt from Constantine to Justinian”, in: Rosario Pintaudi (ed.), Miscellanea Papyrologica (Papyrologica Florentina VII), Florence, 105-116.

Dijkstra (2007): Jitse H. F. Dijkstra, "New light on the Patermouthis archive", in: Bulletin of the American Society of Papyrologists 44, 179-209.

Fournet/Magdelaine 2008: Jean-Luc Fournet and Caroline Magdelaine (eds.), Les archives de Dioscore d'Aphrodité cent ans après leur découverte. Histoire et culture dans l'Égypte Byzantine. Actes du colloque de Strasbourg (8-10 décembre 2005) (Collections de l'Université Marc Bloch - Strasbourg; Études d'archéologie et d'histoire ancienne), Paris.

Fournet (2016): Jean-Luc Fournet, "Sur les premiers documents jurisdiques coptes (2): Les archives de Phoibammôn et de Kollouthos", in: Anne Boud'hors and Catherine Louis (eds.), Études coptes XIV. Seizième journée d'études, Genève 19-21 juin 2013, Paris, 115-141.

Geremek (1969): Hanna Geremek, Karanis, communauté rurale de l'Égypte romaine au II $-1 I^{\mathrm{e}}$ siècle de notre ère (Archiwum filologiczne 17), Wrocław, Warsaw, and Kraków.

Gonis (2008): Nikolaos Gonis, “Notes on the aristocracy of Byzantine Fayum”, in: Zeitschrift für Papyrologie und Epigraphik 166, 203-210.

Habermann (1998): Wolfgang Habermann, "Zur chronologischen Verteilung der papyrologischen Zeugnisse”, in: Zeitschrift für Papyrologie und Epigraphik 122, 144-160.

Hickey (2007): Todd M. Hickey, “Aristocratic landholding and the economy of Byzantine Egypt”, in: Roger S. Bagnall (ed.), Egypt in the Byzantine World 300-700, Cambridge, 288-308.

22 These are now published by Princeton University Press as The rise of Coptic: Egyptian versus Greek in Late Antiquity (2020). 
Jördens (2001): Andrea Jördens,"Papyri und private Archive. Ein Diskussionsbeitrag zur papyrologischen Terminologie”, in: Eva Cantarella and Gerhard Thür (eds.), Symposion 1997, Cologne, 253-267.

Keenan (2007): James G. Keenan, “Byzantine Egyptian villages”, in: Roger S. Bagnall (ed.), Egypt in the Byzantine World 300-700, Cambridge, 226-243.

Lewis (1983): Naphtali Lewis, Life in Egypt under Roman Rule, Oxford.

Martin (1994): Alain Martin, "Archives privées et cachettes documentaires", in: Adam Bülow-Jacobsen (ed.), Proceedings of the $20^{\text {th }}$ International Congress of Papyrologists, Copenhagen, 23-29 August 1992, Copenhagen, 569-577.

Parsons (2007): Peter Parsons, City of the Sharp-Nosed Fish. Greek Papyri Beneath the Egyptian Sand Reveal a Long-Lost World, London.

Pestman (1990): Pieter W. Pestman, The New Papyrological Primer, Leiden.

Ruffini (2008): Giovanni R. Ruffini, Social Networks in Byzantine Egypt, Cambridge.

Schiller (1968): A. Arthur Schiller, "The Budge Papyrus of Columbia University", in: Journal of the American Research Center in Egypt 7, 79-118.

Van Beek (2007): Bart Van Beek, “Ancient archives and modern collections. The Leuven Homepage of Papyrus Archives and Collections", in: Jaakko Frösén, Tiina Purola, and Erja Salmenkivi (eds.), Proceedings of the 24th International Congress of Papyrology, Helsinki, 1-7 August, 2004, Helsinki, vol. II, 1033-1044.

Vandorpe (2009): Katelijn Vandorpe, “Archives and dossiers”, in: Roger S. Bagnall (ed.), The Oxford Handbook of Papyrology, New York, 216-255.

Wilcken (1953): Ulrich Wilcken, “Urkunden-Referat”, in: Archiv für Papyrusforschung und verwandte Gebiete 15, 108-122.

Wilfong (1990): Terry G. Wilfong, "The archive of a family of moneylenders from Jême", in: Bulletin of the American Society of Papyrologists 27, 169-181.

Wilfong (2002): Terry G. Wilfong, Women of Jeme. Lives in a Coptic Town in Late Antique Egypt (New Texts from Ancient Cultures), Ann Arbor. 